\title{
Speaker age estimation and acoustic characteristics: According to pitch and speech rate*
}

\author{
YoonJeong Seo $\cdot$ Jiyoung Shin** \\ Department of Korean Language and Literatures, Korea University, Seoul, Korea
}

\begin{abstract}
This study aimed to investigate the correlation between speaker's chronological age (CA) and perceived age (PA) and to specify the effect of pitch and speech rate as acoustic cue on judging age, using perceptual testing and acoustic analysis. Three tasks were conducted to identify the degree of listener's accuracy about age estimation. Three perception tasks were conducted to measure the accuracy of 80 Korean listeners when presented with different types of speech. In all the tasks, participants listened to speech samples and gave their estimate of the speaker's age in figures. It was found that Korean listeners are able to gauge the age of a speaker fairly precisely. CA and mean PA were positively correlated in all three tasks. It is clear that the amount and type of information included in the voice samples affected the accuracy of a listener's judgement. Moreover, the result revealed that listeners make use of acoustic information such as pitch and speech rate to estimate speaker's age.
\end{abstract}

Keywords: age estimation, perception test, pitch, speech rate

\section{1. 서론}

본 연구는 한국어 화자를 대상으로 연령 지각 실험을 실시하 여, 한국인 청자가 음성 정보만으로 화자의 연령을 얼마나 정확 하게 추측하는지를 밝히고자 하였다. 또한, 연령 지각에 주요한 음성적 단서인 음높이와 발화 속도가 연령을 지각하는 데에 얼마 나 유의미한 영향이 있는지를 검토하고자 하였다.

일상생활 속에서 우리는 이따금 화자와 대면하지 않고 그의 음 성만을 듣는 경험을 한다. 그리고 그 음성을 기반으로 화자의 연
령이나성별, 외양 등을 상상하곤 한다. 이러한 화자 정보 추정은 자신, 혹은 주변 사람이나 실제 인물을 통해 습득된 경험이 있기 에 가능한 것이다. 특히, 연령의 경우에는, 음성이 전 생애를 걸쳐 끊임없이 변화하기 때문에 비교적 추측이 용이한 편이다. 예를 들어, 여성의 목소리가 높고 맑다면 젊은 화자라고 추측할 것이 다. 또한, 화자의 말 속도가 느리고 조음이 부정확하다면 나이가 많은 화자라고 추측할 것이다. 따라서 청자에 따라 연령 지각의 정확도에는 차이가 있겠지만, 대부분의 청자들은 청년 화자와 노 년 화자의 음성적 특성의 차이를 인지하고 이를 근거로 삼아 나

* 이 논문은 2017년 대한민국 교육부와 한국연구재단의 지원을 받아 수행된 연구임 (NRF-2017S1A5A2A01024742).

** shinjy@korea.ac.kr, Corresponding author

Received 1 August 2019; Revised 12 December 2019; Accepted 12 December 2019

(c) Copyright 2019 Korean Society of Speech Sciences. This is an Open-Access article distributed under the terms of the Creative Commons Attribution NonCommercial License (http://creativecommons.org/licenses/by-nc/4.0) which permits unrestricted non-commercial use, distribution, and reproduction in any medium, provided the original work is properly cited. 
름의 합리적인 판단을 내린다고 할 수 있다.

여러 선행 연구에 따르면, 청자들은 음성을 듣는 것만으로도 화 자의 연령을 상당히 정확하게 추측할 수 있다고 한다(Harnsberger et al., 2008; Horri \& Ryan, 1981; Linville, 2001; Ptacek \& Sander, 1966; Ryan \& Burk, 1974; Shipp \& Hollien, 1969). Shipp \& Hollien(1969)에서는 25명의 피험자들에게 20 89세의 남성 175 명이 발화한 문단 낭독 자료를 들려주고 화자의 연령을 추측하도 록 하였다. 그 결과 평균 지각 연령은 실제 연령과 $\mathrm{r}=0.88$ 의 높은 상관을 보였다. 이후 다양한 방식의 연령 지각 연구가 수행되었으 며, 실제 연령과 지각 연령은 $r=0.68$ 에서 $r=0.9$ 사이의 상관을 보이 는 것으로 보고되었다(Huntley et al., 1987; Neiman \& Applegate, 1990; Ryan \& Burk, 1974). 청자의 정확도는 얼마나 정확하게 연 령을 답변하도록 요구받았는지, 그리고 음성 샘플 길이와 유형이 어떠하였는지에 따라 달라지는 것으로 나타났다(Harnsberger et al., 2008; Ptacek \& Sander, 1966; Schotz, 2007).

그러나 실제 연령(Chronological age, 이하 CA)과 지각 연령 (Perceived age, 이하PA) 간의 상관관계를 밝히는 이러한 연구는 한국인을 대상으로는 거의 수행되지 않았다. 연구 목적이 본고와 는 다소 상이하나, Kim \& Seong (2014)에서는 음성의 음높이와 속도를 변조하였을 때 연령 지각에 어떠한 영향이 있는지를 살피 기 위해 한국어 화자를 대상으로 연령 지각 실험을 실시한 바 있 다. 연구자들은 청년 화자와 노년 화자 24 명이 문장 낭독한 자료 의 음높이와 발화 속도를 분석하고, 이를 변조하여 30 명의 피험 자들에게 들려주고 화자의 연령을 7단계 척도로 추측하게 하였 다. 원 발화에서 청년층 여성은 실제 연령보다 더 낮은 연령으로 지각되었고, 청년층남성과 노년층은 실제 연령과 비슷한 수준으 로 지각되었다. 운율 변조된 발화에서는 발화 속도와 음높이의 변조가 연령 지각에 중요한 요소임이 드러났으며, 속도 변조가 청자의 연령 지각에 더 크게 영향을 미치는 것으로 밝혀졌다. 원 발화와 변조 유형들의 지각 결과를 비교 분석한 점에서 흥미로웠 으나, 화자의 연령대와 연령 답변 방식이 제한적이라는 점에서 아쉬움이 있었다.

이에 본고에서는 한국어 화자를 대상으로 연령 지각 실험을 실 시하고, 음성학적 분석을 통해 어떠한 음성 특성이 연령 지각의 단서가 되는지를 검토하고자 한다. 20 대부터 70 대까지의 연령 범 위 내에서 화자를 대체로 균등하게 선정하였고, 피험자에게 특정 한 숫자로 연령을 답하게 요구하여 실험의 난이도를 높게 설정하 였다. 또한, 본 연구에서는 연령과 관련된 다양한 음성 파라미터 가운데, 선행 연구에서 주요하게 논의된 요소인 음높이와 발화 속도에 주목하고자 한다.

더불어, 음성 샘플의 유형이 판단 정확도에 영향을 미쳤다고 밝힌 선행 연구 결과들을 고려하여, 본 연구에서는 한 화자가 수 행한 3 가지 과제로부터 서로 다른 유형의 음성을 추출하여 자극 을 만들어 실험을 진행하였다. 이를 통해, 청자들의 연령 지각이
과제에 따라 어떠한 차이를 보이는지, 어떤 과제가 화자의 연령 을 정확하게 추측하게 하는지를 밝힐 수 있을 것이다.

\section{2. 연구 방법}

\section{1. 자극}

실험 자극을 추출하기 위해 대규모 음성 코퍼스인 '한국어 표 준 음성 데이터베이스'(Shin \& Kim, 2017)를 활용하였다. 방언권 은 수도권으로 한정하였으며, 연령과 성별을 고려하여 20대부터 70 대까지 6 개의 연령 그룹에서 총 40 명의 화자를 선정하였다. 각 연령 그룹별로 남녀 각 4 명씩을 선정하되, 연령대 초반 1 명, 중반 2 명, 후반 1 명이 포함되도록 하였다. 단, 50 대와 60 대 그룹의 경우 는 조건을 충족하는 남성 표본의 수가 충분하지 않아서 1 명을 줄 여 3명씩을 선정하였다. 또, 전체적으로 표본의 수가 적은 70 대 그 룹의 경우는 남녀 1 명씩만을 선정하였다. 그 결과 실험 자극에 쓰 인 자극은 남성 19 명, 여성 21 명으로, 총 40 명의 발화 자극이었다.

그리고 선정된 화자들이 수행한 발화 과제 가운데 ‘자유 말하 기’와 ‘문단 읽기', ‘모음 발성' 과제의 일부를 편집하여 길이가 10 초 내외가 되도록 자극을 만들었다. 자유 발화의 경우, 내용을 검 토하여 화자의 연령 정보가 내용상 드러나지 않을 수 있는 1 개 발 화 정도를 추출하여 자극으로 만들었다. 자극의 평균 길이는 11.8 초(standard deviation, $S D 2.48$ )였다. 낭독 발화의 경우, 주로 공명 음으로 구성된 낭독 문단 중 3 개 문장을 자극으로 만들었는데, 평 균 길이는 9.6초 $(S D 2.18)$ 였다. 모음 발성의 경우, 8 개의 단모음 중 에 ' F, I, T' 세 모음을 추출하였으며, 평균 길이는 5.7 초(SD 2.76)였다. 1

\section{2. 피험자}

실험에 참여한 피험자는 남녀 각 40 명씩 총 80 명이었다. 피험 자의 연령이 연령 지각에 영향을 미칠 수도 있으므로 20대로 한 정하였다. 피험자의 연령은 평균 24.8세(SD 2.76)로, 남성 평균 25.3세 $(S D$ 2.71), 여성 평균 24.3세 $(S D$ 2.73)였다. 피험자의 방언 배경은 특별히 통제하지 않았으나, 상당수의 피험자가수도권 출 신이었다(총 53명). 피험자들은 모두 청력에 이상이 없었으며, 연 령 지각과 관련한 별도의 사전 훈련을 받은 적이 없었다.

\section{3. 실험 방법}

피험자들은 총 3 가지의 연령 지각 과제를 수행하였다. 자유 발 화 과제, 낭독 발화 과제, 모음 발성 과제의 순서로 수행하였다. 자 극 음성을 발화한 화자들의 연령 범위를 별도로 제시하지 않은 상태에서 발화자의 연령을 판단하도록 하였는데, 예를 들어 '29 세'와 같이 구체적인 숫자로 답변하도록 요구하였다. 모든 과제 는 시작하기 전에 1 개의 연습 문제를 풀도록 하였으며, 끝난 후에

1 '모음 발성' 과제는 8 개의 단모음을 일정한 높이와 크기로 3 초 이상 연장 발성하도록 한 과제이므로, 원칙적으로 3 개 모음을 추출하면 10 초 가량의 자극을 얻을 수 있으나, 실제로는 화자마다 발성 길이에 편차가 있었다. 그 결과 모음 발성 자극의 평균 길이는 5.7초(SD 2.76)였다. 
는 과제와 관련된 설문조사에 답하도록 하였다.

\section{4. 분석 방법}

분석을 위하여 전체 응답 결과에서 피험자 정보와 연령에 대한 판단 결과를 추출하였다. 그리고 총 80 명의 피험자가 추정한 화 자의 연령을 화자별로 평균을 내어 지각 연령을 구하였다.

음성 자극 분석에는 Praat 6.0.36을 이용하여, 음높이와 발화 속 도를 측정하였다. 자유 및 낭독 발화 과제의 음높이는 발화 전체 의 $\mathrm{SfO}$ (Speaking fundamental frequency)로 측정하였으며, 모음 발 성 과제의 음높이는 각 모음별 평균 $\mathrm{f0}$ 로 측정하였다. 음높이 측 정을 위해, Script를 이용하여 자동으로 pitchpoint를 추출하고 수 동으로 트래킹 오류를 바로 잡은 후에 각 지점의 $\mathrm{f} 0$ 를 구하였다. 이때 pitchFloor는 화자의 성별에 따라 다르게 설정하였는데, 남 성은 $75 \mathrm{~Hz}$, 여성은 $120 \mathrm{~Hz}$ 로 설정하였다. 낭독 발화는 세 문장의 $\mathrm{Sf} 0$ 를 각각 측정한 후 이들의 평균값으로 제시하였으며, 모음 발성 은 세 모음의 $\mathrm{f} 0$ 를 각각 측정하였다. 한편, 발화 속도는 자유 및 낭 독 발화에 한하여 측정하였으며, 휴지를 포함한 말 속도(speaking speed)를 초당 음절 수(sps)로 제시하였다.

통계 분석과 시각화에는 R 3.4.3 프로그램을 이용하였다. 분석 방법으로 혼합 효과 모형(mixed-effects model)을 선택하였다. ‘지 각 연령’을 종속변수로 설정하고, ‘실제 연령’ ‘화자 성별’, ‘청자 성별, ‘과제 유형, ‘음높이', ‘발화 속도’를 고정변수로, ‘피험자’ 와 ‘실험 자극'을 임의변수로 설정하였다. 이때, 음높이와 발화 속도 값은 성별에 따라 표준화하였으며, 지각 연령과 실제 연령 은 $\log$ 값으로 변환하여 모델을 만들었다.

\section{3. 분석 결과}

\section{1. 지각 연령}

그림 1은 과제에 따라 실제 연령과 평균 지각 연령 간의 상관관 계를 산점도로 나타낸 것이다. 분석 결과, 피험자들은 상당히 높 은 정확도로 화자의 연령을 추정하고 있음을 알 수 있었다. 특히, 자유 발화와 낭독 발화 과제에서는 $\mathrm{CA}$ 와 평균 $\mathrm{PA}$ 간의 차이가 매 우 근소하여, 각각 $R^{2}=0.89$ 와 $R^{2}=0.90(p<.001)$ 로 매우 강한 상관을 보였다. 이에 반해, 모음 발성 과제에서는 $\mathrm{CA}$ 와 평균 $\mathrm{PA}$ 간의 상 관이 상대적으로 낮아졌는 데, $R^{2}$ 값은 $0.54(p<.001)$ 로 나타났다.

또한, 모든 과제에서 평균 $\mathrm{PA}$ 의 범위가 $\mathrm{CA}$ 의 범위보다 좁게 나타났다. CA의 범위는 20 79세였지만, 평균 PA의 범위는 자유 발화 24 73.4세, 낭독 발화 21.8 71.4세, 모음 발성 26.1 62.8세로 나타났다. 자유 발화와 낭독 발화의 경우에는 대다수의 화자가 실제 연령보다 낮은 연령으로 지각되는 경향을 보였다. 실제 연 령보다 높은 연령으로 지각된 화자는 총 14 명이었고(자유 발화 8 명, 낭독 발화 6명), 모두 20 30대 화자들이었다.

\section{자유 발화}

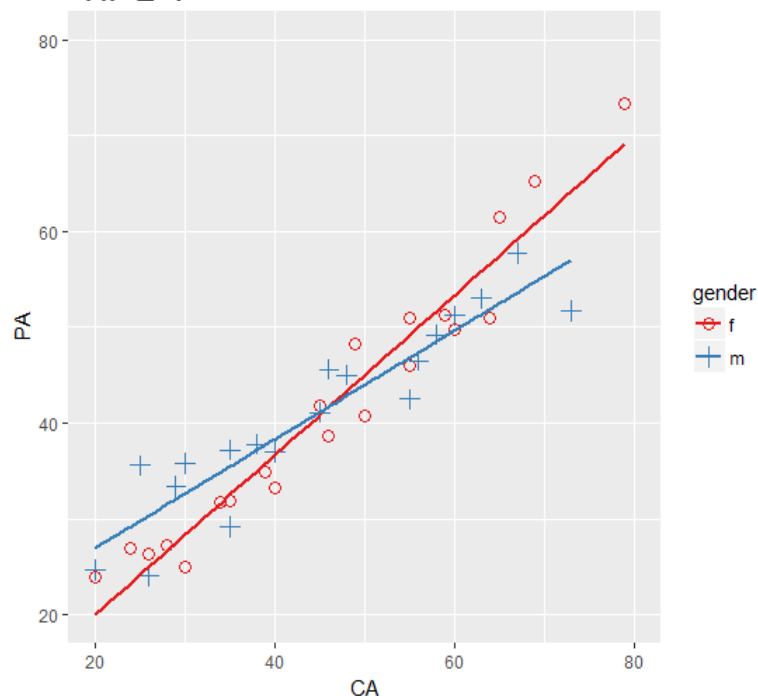

낭독 발화

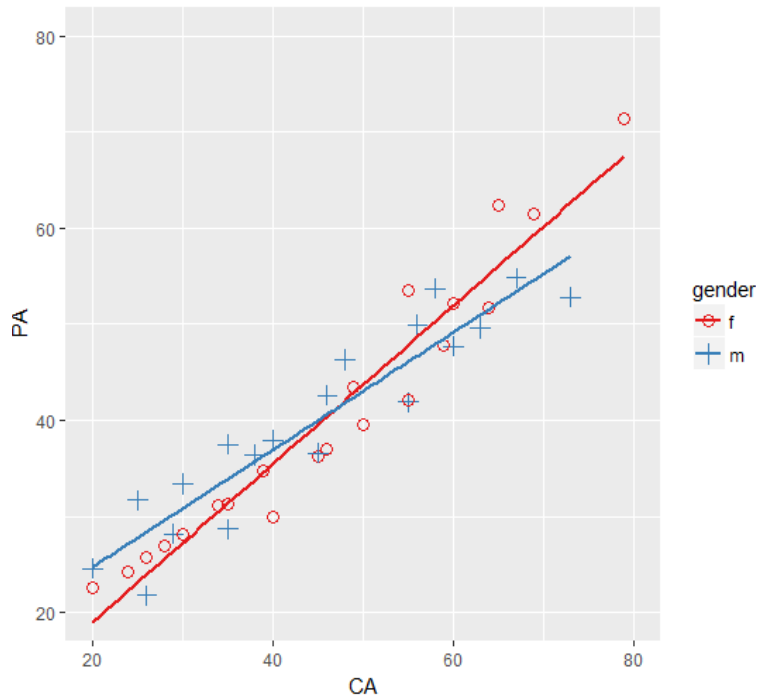

모음 발성

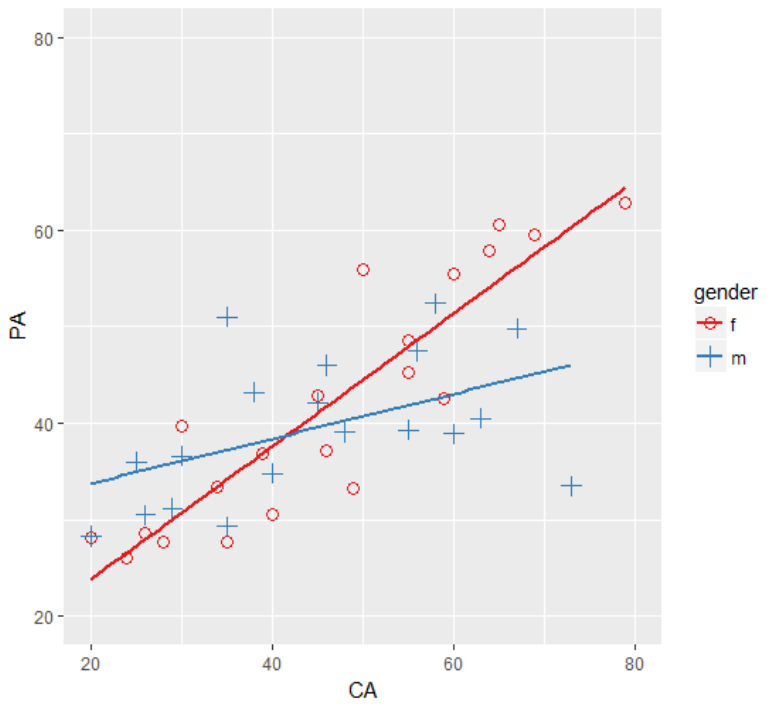

CA, chronological age; PA, perceived age.

그림 1. 과제별 $\mathrm{CA}$ 와 평균 $\mathrm{PA}$ 의 상관관계 Figure 1. Relationship between CA and mean PA 
그리고 본 연구에서는 피험자의 연령을 20 대로 한정하였고, 이로 인해 중년 및 노년 화자 집단의 연령 지각 정확도가 상대적 으로 낮을 것이라 예상하였다. Shipp \& Hollien (1969)에서는 PA 의 표준편차 값이 20 대 그룹에서는 가장 작게 나타나는 것을 피 험자들의 연령과 상관이 있다고 보았다. 즉, 피험자가 20 30대에 국한되어 있었기 때문에, 다른 연령대보다 20대 화자의 연령을 지각하는 것이 쉬웠을 것이라고 본 것이다. 이에 본 연구에서도 그림 2와 같이, $\mathrm{CA}$ 와 $\mathrm{PA}$ 의 표준편차 값, 그리고 $\mathrm{PA}$ 와 $\mathrm{PA}$ 표준편 차 값과의 상관관계를 살펴보았다. $\mathrm{CA}$ 및 $\mathrm{PA}$ 의 증가에 따라 $\mathrm{PA}$ 표준편차도 증가하는 선형성이 나타났다. 이러한 양상은 낭독 발 화 과제뿐만 아니라, 자유 발화 과제와 모음 발성 과제에서도 모 두 공통적으로 나타났다. 2

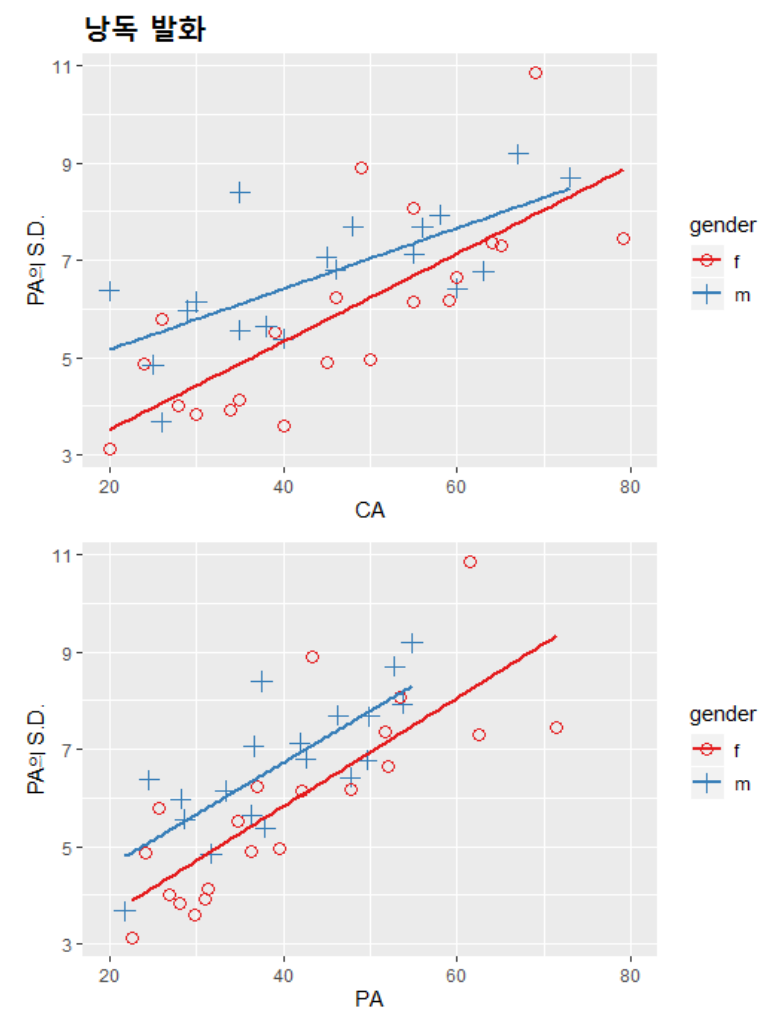

CA, chronological age; PA, perceived age.

그림 2. 낭독 발화에서의 연령과 $\mathrm{PA} \mathrm{SD}$ 의 상관관계(상: $\mathrm{CA}$, 하: $\mathrm{PA}$ )

Figure 2. Relationship between age and PA $S D$ in read speech

더불어, 과제 유형과 성별이 연령 지각에 영향이 있는지 확인 하기 위하여, 표 1 과 같이 과제 유형과 화·청자의 성별에 따라 CA 와 PA의 피어슨 상관 계수를 구하였다. 이때 $\mathrm{PA}$ 는 평균값이 아닌 개별 피험자의 응답 전체를 대상으로 하였다. 분석 결과, 자유 발 화와 낭독 발화에서는 화.청자의 성별과 관계없이 $\mathrm{CA}$ 와 $\mathrm{PA}$ 가 강 한 상관을 보였다. 또한, 이 두 과제에서 남성 화자보다는 여성 화 자의 상관 계수가 상대적으로 더 큰 값을 보였는데, 이는 피험자
들이 여성 화자를 실제 연령에 더 가깝게 추정한 결과로 해석할 수 있다. 한편, 청자의 성별에 따라서는 상관 계수가 큰 차이를 보 이지 않았다.

표 1. 과제 및 화·청자 성별에 따른 $\mathrm{CA}$ 와 $\mathrm{PA}$ 의 상관 계수 $(p<.001)$ Table 1. Pearson's $r$ about CA and PA $(p<.001)$

\begin{tabular}{c|c|c|c|c}
\hline \multicolumn{2}{|c|}{ 구분 } & \multicolumn{3}{c}{ 과제 유형 } \\
\hline \multirow{2}{*}{ 화자 } & 성별 & 자유 발화 & 낭독 발화 & 모음 발성 \\
\cline { 2 - 5 } & 여성 & 0.90 & 0.88 & -0.35 \\
\cline { 2 - 5 } & 남성 & 0.78 & 0.77 & -0.18 \\
\hline \multirow{2}{*}{ 청자 } & 여성 & 0.86 & 0.84 & -0.25 \\
\cline { 2 - 5 } & 남성 & 0.84 & 0.83 & -0.23 \\
\hline
\end{tabular}

CA, chronological age; PA, perceived age.

3.2. 음높이와 지각 연령

본 연구에서 실제 연령에 따른 음높이의 변화는 여성 화자 집 단에서만 뚜렷하게 관찰되었다. 여성 화자는 나이가 많을수록 음 높이가 낮은 경향을 보였으나, 통계적으로 유의한 수준은 아니었 다. 남성 화자의 경우에는 세 과제에서 모두 실제 연령과 음높이 간의 뚜렷한 상관이 관찰되지 않았다. 아래의 표 2 는 연령 그룹, 성별, 과제에 따른 평균 $\mathrm{Sf0}$ 와 $\mathrm{f0}$ 를 요약한 것이다.

표 2. 연령 그룹, 성별, 과제에 따른 $\mathrm{Sf0}$ 와 $\mathrm{f0}$ (단위: $\mathrm{Hz}$, 괄호 안은 $S D$ ) Table 2. Sf0 and f0 according to age group, gender, and task (Hz, (SD))

\begin{tabular}{|c|c|c|c|c|}
\hline $\begin{array}{l}\text { 연령 } \\
\text { 그룹 }\end{array}$ & 성별 & 자유 발화 & 낭독 발화 & ' F' 발성 \\
\hline \multirow{2}{*}{ 20대 } & 여성 & $204.2(14.24)$ & $198.7(19.50)$ & $203.2(5.99)$ \\
\hline & 남성 & $120.6(24.47)$ & $112.4(17.01)$ & $103.3(14.64)$ \\
\hline \multirow{2}{*}{ 30대 } & 여성 & $217.4(34.87)$ & $192.0(18.54)$ & $186.9(22.79)$ \\
\hline & 남성 & $129.4(27.11)$ & $126.7(24.15)$ & $111.6(18.86)$ \\
\hline \multirow{2}{*}{ 40대 } & 여성 & 218.2 & 195.4 & $191.6(17.28)$ \\
\hline & 남성 & $145.6(29.75)$ & $125.7(19.10)$ & $133.0(34.76)$ \\
\hline \multirow{2}{*}{ 50대 } & 여성 & $209.2(11.08)$ & $183.9(5.48)$ & $198.6(18.33)$ \\
\hline & 남성 & $133.1(18.81)$ & $127.7(31.40)$ & $124.3(21.60)$ \\
\hline \multirow{2}{*}{$\begin{array}{c}60 \sim \\
70 \text { 대 }\end{array}$} & 여성 & $172.5(29.42)$ & $165.3(12.81)$ & $157.9(8.20)$ \\
\hline & 남성 & $106.7(12.02)$ & $107.1(6.90)$ & $103.4(2.00)$ \\
\hline
\end{tabular}

그림 3 은 과제에 따라 음높이와 평균 지각 연령 간의 상관관계 를 나타낸 것이다. 평균 PA에서도 남성 화자보다는 여성 화자가 음높이와 뚜렷한 상관을 보였다. 즉, 피험자들은 음높이가 높은 여성의 경우 연령이 낮다고 지각하고, 음높이가 낮은 여성의 경 우 연령이 높다고 지각하는 경향을 보였다. 특히, 낭독 발화와 모 음 발성에서 유의한 수준에서 상관이 관찰되었으며, 모음 발성에 서 상대적으로 더 강한 상관이 나타났다(자유 발화 $R^{2}=0.11$

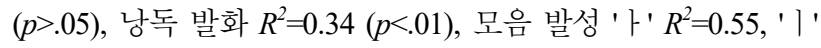
$\left.R^{2}=0.68,{ }^{\prime} \top^{\prime} R^{2}=0.58(p<.001)\right)$.

남성 화자의 경우, 자유 발화와 낭독 발화에서는 음높이와 평

2 지면의 제한으로 낭독 발화 과제의 결과만 제시하였다. 세 과제 가운데 낭독 발화 과제를 택한 것은, 서론에서 소개하였듯이 Shipp \& Hollien (1969)의 연구가 낭독 발화 자료를 바탕으로 수행되었기 때문이다. 


\section{자유 발화}

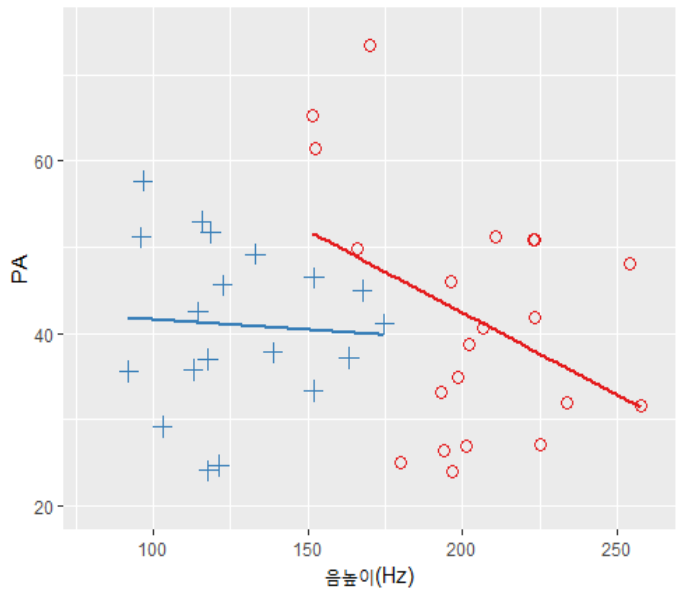

낭독 발화

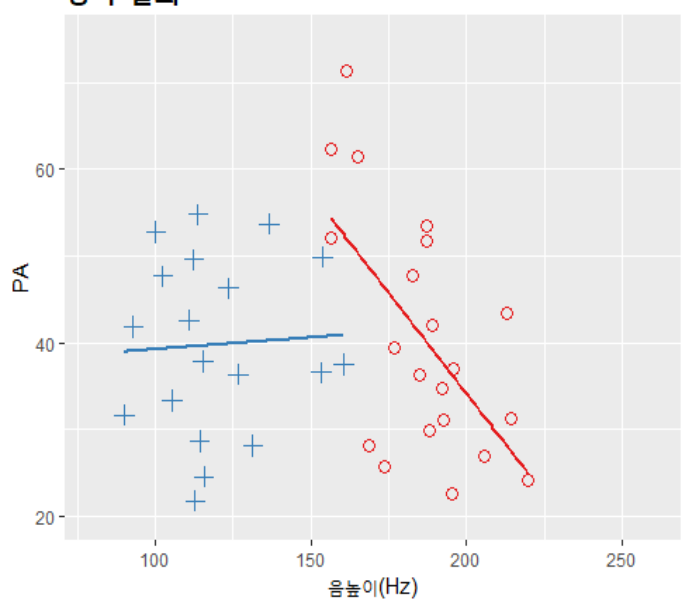

모음 발성

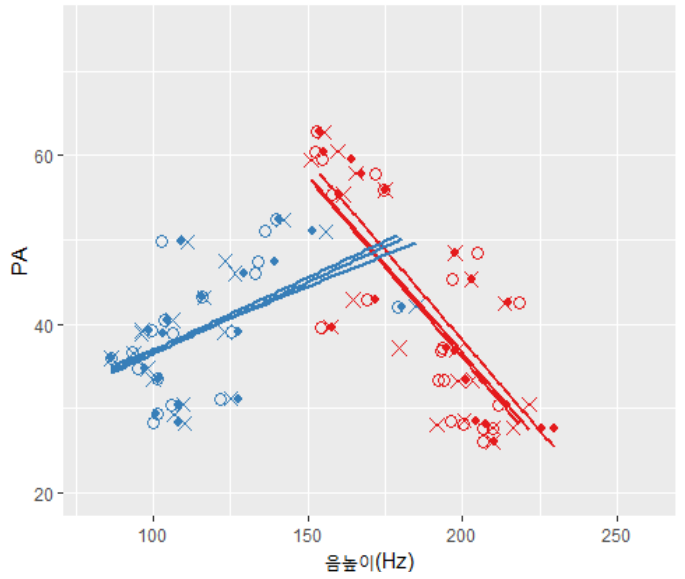

PA, perceived age.

그림 3. 과제별 음높이와 평균 $\mathrm{PA}$ 의 상관관계

Figure 3. Relationship between pitch and mean PA

균 PA 간의 뚜렷한 경향성이 관찰되지 않았다. 다만, 모음 발성에 서는 미약한 상관관계를 관찰할 수 있었다(자유 발화 $R^{2}=-0.05$ ( $p>05)$, 낭독 발화 $\mathrm{R}^{2}=-0.06$ ( $\left.p>.05\right)$, 모음 발성 ' ' ' $\mathrm{R}^{2}=0.23$, ' । ' $\mathrm{R}^{2}=0.19$, , $\left.^{\prime} \mathrm{R}^{2}=0.24(p<.05)\right)$.
표 3. 회귀 분석 결과 요약 (1): 전체 데이터에서의 각 고정변수와 $\mathrm{PA}$ 의 관계

Table 3. Regression analysis result (1): relations between PA and fixed effects in whole data

\begin{tabular}{|c|c|c|c|}
\hline 고정효과 & $\beta$ & SE & $\mathrm{t}$-value \\
\hline $\mathrm{CA}^{* * *}$ & 0.294 & 0.025 & 11.614 \\
\hline 화자 성별(남성) ${ }^{*}$ & -0.318 & 0.136 & -2.339 \\
\hline 청자 성별(남성)** & 0.322 & 0.121 & 2.666 \\
\hline 과제 유형(자유) & 0.130 & 0.123 & 1.154 \\
\hline 과제 유형(모음) & 1.292 & 0.103 & 12.615 \\
\hline 음높이 ${ }^{* *}$ & 0.306 & 0.101 & 3.023 \\
\hline
\end{tabular}

$\mathrm{PA}$, perceived age; CA, chronological age.

표 3의 회귀 분석 결과는 종속변수인 PA와 5가지 고정변수의 관계를 제시한 것이다. 모음 발성 과제의 경우에는 발화 속도 값 이 존재하지 않기 때문에, 발화 속도는 고정변수에서 제외되었 다. 위의 결과에서 기준이 되는 값은 여성 화자의 낭독 발화를 듣 고 여성 피험자가 판단한 $\mathrm{PA}$ 이다. 고정효과 가운데 통계적으로 유의한 영향력을 가지는 변수는 $\mathrm{CA}$ 와 화자의 성별, 청자의 성별, 과제 유형, 음높이로 나타났다.

변수간의 상호작용 효과도 관찰되었는데, 표 4는 $\mathrm{PA}$ 의 예측에 유의한 영향력을 갖는 변수 간 상호작용 효과를 제시한 것이다. 화자의 성별과 모음 발성 과제, 음높이 변수 간의 상호작용 효과 가 관찰되었다는 점을 주목할 만하다.

표 4. 전체 데이터에서의 변수 간의 상호작용 효과 Table 4. Interaction effects in whole data

\begin{tabular}{|c|c|c|}
\hline 상호작용 효과 & $\beta$ & t-value \\
\hline $\mathrm{CA}$ : 화자(남성) ${ }^{* *}$ & -0.091 & 3.290 \\
\hline $\mathrm{CA}$ : 청자(남성) ${ }^{* *}$ & -0.427 & -2.760 \\
\hline $\mathrm{CA}:$ 과제 $(\text { 모음 })^{* * *}$ & -0.062 & -11.604 \\
\hline 청자(남성): 과제(모음) ${ }^{* *}$ & -0.541 & -3.204 \\
\hline $\mathrm{CA}$ : 음높이 ${ }^{*}$ & -0.272 & -2.301 \\
\hline 화자(남성) : 음높이 ${ }^{* * *}$ & 0.107 & -3.517 \\
\hline 과제(모음) : 음높이 ${ }^{*}$ & 0.036 & -2.467 \\
\hline $\mathrm{CA}$ : 화자(남성) : 과제(모음) ${ }^{* *}$ & 0.102 & -2.584 \\
\hline $\mathrm{CA}$ : 청자(남성 $)$ : 과제(모음) ${ }^{* *}$ & -0.099 & 2.948 \\
\hline$\overline{\mathrm{CA}}$ : 화자(남성) : 음높이 ${ }^{*}$ & 0.102 & 2.495 \\
\hline 화자(남성) : 과제(모음) : 음높이 ${ }^{* *}$ & 0.524 & 3.146 \\
\hline$\overline{\mathrm{CA}}$ : 화자(남성) : 과제(모음) : 음높이 ${ }^{*}$ & -0.099 & -2.235 \\
\hline
\end{tabular}

\section{3. 발화 속도와 지각 연령}

실제 연령에 따른 발화 속도의 변화는 낭독 발화 과제에서 뚜 렷하게 관찰되었다. 낭독 발화에서 $\mathrm{CA}$ 와 발화 속도의 상관관계 는 남성 화자 $R^{2}=0.46(p<.001)$, 여성 화자 $R^{2}=0.62$ ( $\left.p<.001\right)$ 로 나타 났다. 한편, 자유 발화에서는 낭독 발화와는 달리 뚜렷한 상관을 관찰하기 어려웠다. 아래의 표 5는 연령 그룹, 성별, 과제에 따른 평균 발화 속도를 요약한 것이다. 
표 5. 연령 그룹, 성별, 과제에 따른 발화 속도 (단위: sps, 괄호 안은 $S D$ ) Table 5. Speech rate according to age group, gender, and task (sps, $(S D)$ )

\begin{tabular}{c|c|c|c}
\hline 연령 그룹 & 성별 & 자유 발화 & 낭독 발화 \\
\hline \multirow{2}{*}{20 대 } & 여성 & $5.4(0.54)$ & $7.6(0.42)$ \\
\cline { 2 - 4 } & 남성 & $5.3(0.74)$ & $7.5(0.47)$ \\
\hline \multirow{2}{*}{30 대 } & 여성 & $5.6(0.79)$ & $6.4(1.04)$ \\
\cline { 2 - 4 } & 남성 & $5.2(1.01)$ & $6.7(0.61)$ \\
\hline \multirow{2}{*}{40 대 } & 여성 & $5.2(0.93)$ & $5.9(0.89)$ \\
\cline { 2 - 4 } & 남성 & $5.4(0.55)$ & $6.5(0.88)$ \\
\hline \multirow{2}{*}{50 대 } & 여성 & $5.8(0.92)$ & $5.9(1.34)$ \\
\cline { 2 - 4 } & 남성 & $5.1(0.23)$ & $6.5(0.88)$ \\
\hline \multirow{2}{*}{$60 ~ 70$ 대 } & 여성 & $3.8(1.01)$ & $4.1(0.60)$ \\
\cline { 2 - 4 } & 남성 & $3.9(0.97)$ & $5.0(0.55)$ \\
\hline
\end{tabular}

다시 말해, 성별에 무관하게 연령이 높은 화자일수록 낭독 시 느린 발화 속도를 보이는 경향을 확인할 수 있었다. 20대와 60 70 대 집단의 초당 음절수를 비교해 보면 청년 화자와 노년 화자의 차이를 분명히 알 수 있다. 20대는 평균 7.6 $\mathrm{sps}(S D 0.42)$ 의 속도로 낭독한 반면, 60 대는 $4.5 \mathrm{sps}(S D$ 0.86), 70대는 $4.4 \mathrm{sps}(S D$ 0.47)의 속도로 낭독한 것으로 나타나, 초당 3 음절 정도의 차이를 보였다. $30-50$ 대의 경우, 각각 $6.5 \mathrm{sps}(S D \quad 0.80), 6.2 \mathrm{sps}(S D \quad 0.87), 6.1$ $\operatorname{sps}(S D$ 1.14)로, 20대보다는 느리고 60 70대보다는 빠른 발화 속 도를 보였다.

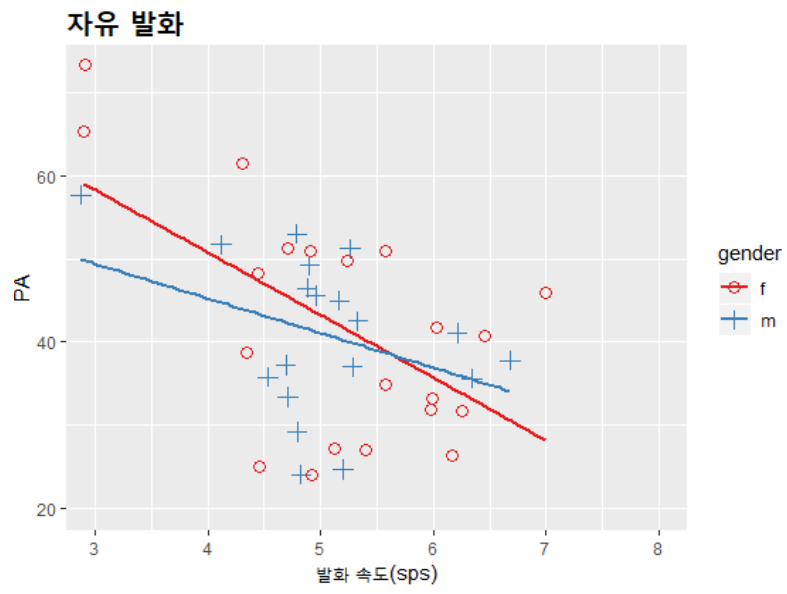

낭독 발화

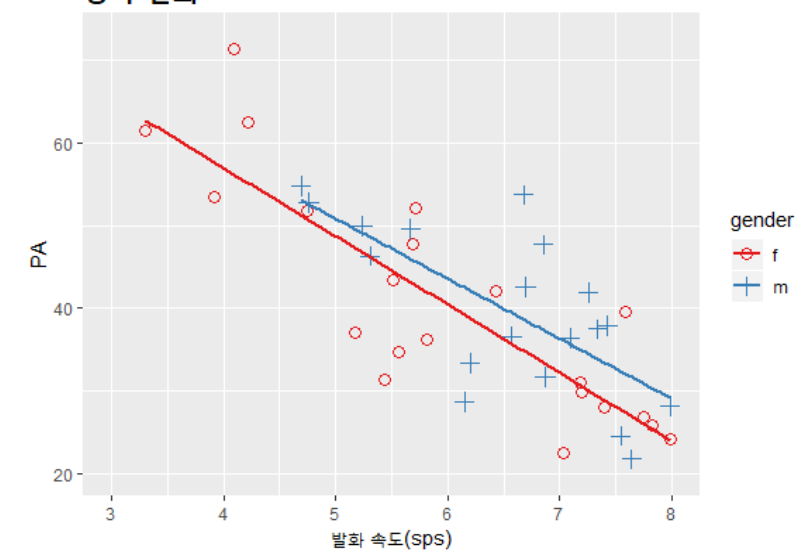

PA, perceived age.

그림 4. 과제별 발화 속도와 평균 $\mathrm{PA}$ 의 상관관계 Figure 4. Relationship between pitch and mean PA
자유 발화의 경우, 대본 없이 즉흥적으로 독백 발화를 수행한 것이므로, 전반적으로 낭독 발화보다 발화 속도가 느리며 휴지가 잦고 긴 편이었다. 연령에 따른 발화 속도 차이도 두드러지지 않 았다. 하지만 노년 집단과 청·장년 집단 간의 속도 차이는 여전히 존재하였다. 노년 집단인 60 70대의 말 속도는 평균 $4 \mathrm{sps}$ 이하로, 청·장년 집단에 비해 상대적으로 느린 발화 속도를 보여주었다.

그림 4는 과제에 따라 발화 속도와 평균 PA 간의 상관관계를 제시한 것이다. 대체적으로 발화 속도가 느릴수록 나이가 많은 화자로 지각된 것을 알 수 있으며, 이러한 경향성은 낭독 발화에 서 두드러지게 관찰되었다. 남성의 자유 발화를 제외하면 발화 속도와 평균 PA는 유의한 수준에서 상관을 보였으며, 여성의 낭 독 발화에서는 강한 상관이 관찰되었다(자유 발화 남성 $R^{2}=0.8$ ( $p>.05)$, 자유 발화 여성 $R^{2}=0.29(p<.01)$, 낭독 발화 남성 $R^{2}=0.47$ $(p<.001)$, 낭독 발화 여성 $\left.R^{2}=0.7(p<.001)\right)$.

자유 발화와 낭독 발화 과제에 대한 응답 결과로 데이터를 한 정하여 회귀 분석을 수행한 결과, $\mathrm{PA}$ 와 6 가지 고정변수의 관계는 표 6과 같이 나타났다. 기준이 되는 값은 여성 화자의 낭독 발화를 듣고 여성 피험자가 판단한 $\mathrm{PA}$ 이다. 고정효과 가운데 통계적으 로 유의한 영향력을 가지는 변수는 CA와 화자 성별, 청자 성별, 발화 속도라 할 수 있다. 모음 발성 과제 데이터가 제외되면서 음 높이 변수는 주효과를 가지는 변수에서 제외된 것으로 보인다.

그리고 표 7은 변수 간의 상호작용 효과를 요약한 것이다. 성 별과 발화 속도 변수 간의 상호작용 효과가 있음을 주목할 만하 다. 또한, 자유 발화 과제와 낭독 발화 과제로 데이터의 규모를 축소하였을 때에도 과제와 음높이 간의 상호작용 효과가 나타 난다는 점도 확인할 수 있다.

표6. 회귀 분석 결과 요약 (2): 자유/낭독 과제 데이터에서의 각 고정변수와 $\mathrm{PA}$ 의 관계 Table 6. Regression analysis result (2): relations between PA and fixed effects in sponatneous/read data

\begin{tabular}{|c|c|c|c|}
\hline 고정효과 & $\beta$ & $\mathrm{SE}$ & $t$-value \\
\hline $\mathrm{CA}^{* * *}$ & 0.834 & 0.074 & 11.314 \\
\hline 화자 성별(남성)* & 0.870 & 0.406 & 2.141 \\
\hline 청자 성별(남성)* & 0.331 & 0.168 & 1.971 \\
\hline 과제 유형(자유) & 0.034 & 0.193 & 0.177 \\
\hline 음높이 & 0.396 & 0.230 & 1.720 \\
\hline 발화 속도 ${ }^{* * *}$ & 0.612 & 0.147 & 4.174 \\
\hline
\end{tabular}

$\mathrm{PA}$, perceived age; $\mathrm{CA}$, chronological age.

표 7. 자유/낭독 과제 데이터에서의 변수 간의 상호작용 효과 Table 7. Interaction effects in sponatneous/read data

\begin{tabular}{|c|c|c|}
\hline 상호작용 효과 & $\beta$ & t-value \\
\hline CA: 청자(남성) ${ }^{*}$ & -0.094 & -2.140 \\
\hline 과제(자유) : 음높이 ${ }^{* *}$ & -0.730 & -3.116 \\
\hline CA : 발화 속도 ${ }^{* * *}$ & -0.178 & -4.414 \\
\hline 화자(남성) : 발화 속도 ${ }^{* * *}$ & -0.877 & -3.651 \\
\hline CA : 과제(자유) : 음높이 ${ }^{* * *}$ & 0.202 & 3.297 \\
\hline$\overline{\mathrm{CA}}$ : 화자(남성) : 발화 속도 ${ }^{* * *}$ & 0.244 & 3.893 \\
\hline CA : 과제(자유) : 음높이 : 발화 속도 & 0.101 & 1.977 \\
\hline
\end{tabular}




\section{4. 논의}

4.1. 연령 지각의 영향 요인

선행 연구에서 어떠한 음성 샘플이 제시되는지에 따라서 피험 자들의 정확도가 달라졌으므로, 본 연구에서는 정보량에 차이가 있는 세 가지 유형의 샘플을 준비하였다. 연령 지각의 단서로 삼 을 수 있는 정보는 자유 발화 과제가 가장 많이 담고 있었다. 본고 에서 주목한 음성적 단서인 음높이나 발화 속도는 물론, 억양이 나 말투, 발화 내용 등을 통해서도 연령을 가늠할 수 있기 때문이 다. 이에 반해, 모음 발성 과제는 가장 적은 정보를 담고 있었다. 연장 발성된 세 모음으로부터 음높이나 음의 떨림, 음색과 같은 음성적 단서만을 포착할 수 있기 때문이다.

분석 결과, 10 초 내외의 짧은 음성만으로도 피험자들은 화자 들의 연령을 실제에 가깝게 판단할 수 있는 것으로 밝혀졌다. 모 음 연장 발성과 같이 극히 제한적인 음성 유형에서도 대략적인 판단이 가능하다는 것을 확인하였다. 즉, 청자들은 경험적으로 연령과 관련된 음성적 특성을 알고 있으며, 이를 근거하여 상당 히 정확한 추론을 한다고 해석할 수 있다.

그리고 과제 간의 비교를 통해 연령 지각의 정확도는 음성에 담긴 정보의 양과 유관하다는 것을 알 수 있었다. 정보량이 극히 적은 모음 발성의 경우, 자유 발화나 낭독 발화보다 정확도가 현 저히 낮게 나타났다. 단적인 예로, 35세 남성 화자는 자유 발화와 낭독 발화에서는 실제 연령과 평균 지각 연령이 근소한 차이를 보였으나(자유 발화 37.2세(SD 6.80), 낭독 발화 37.5세(SD 8.40)), 모음 발성에서는 평균 지각 연령이 51세(SD 11.41)로 추정되어 상당히 큰 오차를 보였다. 회귀 분석 결과에서도 자유 발화 과제 와 낭독 발화 과제는 유의한 차이를 보이지 않았으나, 모음 발성 과제는 다른 두 과제와 유의한 차이를 보였다.

실제로, 많은 피험자가 세 과제 가운데 모음 발성 과제에서의 판단이 가장 어려웠다고 응답하였다. 지각 실험 후 실시한 설문 조사 결과에 따르면 가장 판단이 어려운 과제를 묻는 문항에서 총 45명의 피험자가 모음 발성 과제가 가장 어려웠다고 답했다. 피험자들은 다른 과제와 달리 ‘주어진 정보가 제한적’이고 ‘말투 나억양이 드러나지 않기’ 때문에 ‘목소리만으로' 연령을 판단하 는 것이 힘들었다고 답변하였다.

그럼에도 모음 발성 과제에서 $\mathrm{CA}$ 와 평균 $\mathrm{PA}$ 의 $R^{2}$ 값은 0.54 로 나타나, 매우 제한적인 음성 정보만으로도 피험자들은 화자의 연 령을 어느 정도 짐작할 수 있다고 볼 수 있다. 더욱이 여성 화자로 한정하면, 모음 발성 과제에서도 $R^{2}$ 값이 $0.80(p<.001)$ 으로 상당 히 강한 상관을 보였다. 이러한 결과는 음높이 정보가 연령 지각 에 활용되었음을 뒷받침해 준다고 할 수 있다. 모음 발성 과제는 다른 두 과제보다 화자 간 음높이 차이에 주목하는 것이 상대적 으로 더 쉽고, 제한적인 정보량으로 인해 이에 의존할 수밖에 없 기 때문이다. 이에 대해서는 4.2절에서 논의하도록 하겠다.

한편, 자유 발화 과제와 낭독 발화 과제에서는 피험자들이 실 제 연령에 매우 가깝게 화자의 연령을 추측하였다는 사실도 흥미 롭다. 자유 발화 과제에서 화자 특성이 보다 풍부하게 드러날 것 이므로 낭독 발화 과제보다 연령 지각의 정확도가 더 높을 것이
라 예상하였다. 그러나 발화 속도가 연령 판단에 주요한 단서가 된 것을 고려할 때, 낭독 발화 과제는 모든 화자가 동일한 문장을 발화한 것이므로 조음 속도나 휴지 패턴의 차이를 포착하기 용이 하여 판단의 정확도가 높게 나타난 것으로 보인다.

또한, 회귀 분석 결과에 따르면 화·청자의 성별도 PA에 유의한 영향이 있는 것으로 나타났다. 실제로 피험자들은 남성 화자보다 여성 화자의 연령을 상대적으로 더 실제에 가깝게 추측하는 경향 을 보였다. 게다가 모음 발성 과제의 경우, 남성 화자에 대한 연령 추측은 사실상 실패하였다고 할 수 있는데, 그림 1을 보면 대부분 의 남성 화자들은 30 40대로 판단된 것을 확인할 수 있다. 음높이 와 발화 속도 같은 음성적 단서들이 여성 화자들 사이에서 상대 적으로 더 큰 차이를 보였기 때문에, 피험자들은 여성 화자의 음 성을 변별하기 더 수월했을 것으로 보인다.

그러나피험자의 성별이 연령 지각에 어떠한 영향을 주는 것인 지는 분명하지 않다. 표 1 에서 살펴본 것처럼, 남성 피험자와 여 성 피험자의 판단 결과가 큰 차이를 보이지 않았기 때문에, 여성 피험자가 더 실제 연령에 가까운 판단을 내렸다고 단정하기는 어 렵다. 자신과 동성인 화자의 연령을 비교적 더욱 용이하게 추측 할 수 있으리라 가정할 수 있으나, 본 연구 결과에서는 화자 성별 과 청자 성별 간의 상호작용 효과가 관찰되지 않아서 이를 확인 하기는 어렵다.

그리고피험자 자신의 연령이 화자의 연령 지각에 영향을 주었 을 가능성도 확인해 보았다. Shipp \& Hollien (1969)에서는 PA 표 준편차가 청년 및 노년 화자 집단에서는 작고 중년 화자 집단에 서는 커서, $\mathrm{CA}$ 에 따른 PA 표준편차의 산점도를 그렸을 때 곡선성 (curvilinearity)이 관찰되었다. 이는 중년 화자 집단 판단할 때보 다 청년 및 노년 화자 집단을 판단할 때 피험자들 간의 PA 값의 편 차가 더 작다는 것을 보여주는 결과였다. 그리고 PA와 PA 표준편 차 간의 관계에서는 이러한 곡선성이 더욱 뚜렷하게(more pronounced) 나타났다.

그러나 본 연구에서는 Shipp \& Hollien (1969)와 동일하게 대학 생을 대상으로 실험을 진행하였음에도 그러한 곡선성은 관찰되 지 않았다. 대신, CA나 PA의 증가에 따라 PA 표준편차도 증가하 는 선형성이 나타났다(그림 2). 이러한 양상은 세 과제에서 모두 공통적으로 나타났다. 다시 말해, 나이가 많은 화자의 음성일수 록 피험자들의 판단이 더 큰 차이를 보인 것이라 할 수 있다. 이는 피험자들이 자신과 주변인의 음성을 바탕으로 경험적인 추정을 내리기 때문에 나타난 결과로 해석된다.

마지막으로, 모든 과제에서 평균 $\mathrm{PA}$ 의 범위가 $\mathrm{CA}$ 의 범위보다 좁다는 점을 주목할 필요가 있다(CA 범위: 20 79세, 평균 PA 범 위: 자유 24 73.4세, 낭독 21.8 71.4세, 모음 26.1 62.8세). 이는 청 년 화자의 연령은 실제보다 과대평가되고(overestimate), 노년 화 자의 연령은 과소평가된(underestimate) 결과라 할 수 있다. 이러 한 결과는 Shipp \& Hollien (1969)에서도 보고된 바 있다. 본 연구 에서는 노년 화자의 연령이 과소평가되는 경향이 특히 강하게 나 타났는데, 이를 통해 20대 피험자들은 노년층의 전형적인 음성을 실제보다 더 나이 든 음성으로 상정하고 있다고 볼 수 있다. 
4.2. 연령 지각의 음성적 단서

음높이와 발화 속도는 연령에 따른 음성적 변화와 밀접한 관련 이 있으며, 연령 지각에 중요한 단서임이 여러 연구를 통해 보고 되었다. 이 때문에 Harnsberger et al. (2008)과 Kim \& Seong (2014) 와 같이, 음높이와 발화 속도를 조작하여 연령 지각 실험을 수행 한 연구들도 존재한다. 이 연구들을 통해 음높이보다 발화 속도 가 연령 지각에 더 크게 영향을 미친다는 사실이 밝혀진 바 있다. 본 연구에서도 화자의 연령을 지각하는 데에는 음높이보다 발화 속도가 더욱 큰 단서가 된 것으로 보인다.

\subsection{1. 음높이}

성인 여성의 음높이는 중년까지는 안정적으로 유지되다가, 갱 년기 이후로 낮아지는 특징을 보인다. 반면에, 성인 남성의 음높 이는 청소년기 이후로 중년이 될 때까지 낮아지다가, 노년에 급 격히 상승하는 특징을 보인다. 이로 인해, 나이가 들수록 여성과 남성의 음높이 차이가 줄어드는 양상을 보인다(Baken, 2005).

그러나 본 연구에서 40 명의 화자의 음높이는 연령에 따른 차 이를 분명하게 보이지 않았다. 남성의 경우에는 여성에 비해 화 자 간 음높이 차이가 크지 않았으며, 실제 연령과 음높이 간의 상 관도 유의미하지 않았다. 여성의 경우에는 낭독과 모음 발성에서 연령에 따라 음높이가 하락하는 경향이 미약하게 관찰되었다. 따 라서 피험자들이 음높이 단서를 기반으로 연령을 추정하는 것이 어려웠을 것으로 생각된다.

자유 발화에서는 성별에 무관하게 음높이와 PA 간의 유의한 상관이 나타나지 않았다. 자유 발화에서는 음높이 외에도 연령을 추정할 단서들이 다수 존재하므로, 여러 단서가 복합적으로 연령 을 판단하는 데에 영향을 주었을 것이다. 다만, 여성 화자 가운데 60 대 이상으로 지각된 화자들의 $\mathrm{Sf} 0$ 가 $170 \mathrm{~Hz}$ 이하로, 여성 집단 내에서 매우 낮은 음높이를 보였다는 점은 주목할 만하다. 이 3 명 의 화자들은 다른 음성적 단서와 함께 낮은 음높이가 피험자의 판단에 영향을 주었을 것으로 짐작할 수 있다.

낭독 발화에서도 남성 화자의 경우 음높이와 PA는 별다른 상 관관계를 보이지 않았다. 여성 화자의 경우에는 약한 상관을 보 였지만, 자유 발화와 마찬가지로 노년 화자를 나머지 화자들과 구분하게 하는 정도의 기여를 한 것으로 보인다.

반면에, 모음 발성에서는 참고할 수 있는 음성적 단서가 거의 존재하지 않았기 때문에, 음높이 정보와 PA 간의 상관이 상대적 으로 높게 나타난 것으로 짐작된다. 그리고 남성 화자보다는 여 성 화자에게서 연령에 따른 음높이의 차이가 더 선명하게 존재하 였기 때문에, 음높이와 PA의 상관이 여성 화자에게서 더 크게 나 타난 것으로 해석된다. 회귀 분석에서 화자의 성별과 모음 발성 과제, 음높이 변수 간의 상호작용 효과가 관찰된 것도 이에 따른 것이라 할 수 있다.

결론적으로, 음높이 단서는 화자 연령 지각에 부분적으로 이 용된 것이라 할 수 있다. 특히, 화자가 여성일 경우에는 음높이 정 보가 더욱 적극적으로 판단의 단서가 되었으며, 음높이가 낮을수 록 나이가 많다고 판단되었다. 그리고 모음 발성 과제와 같이 단 서로 삼을 음성 정보가 부족한 경우에는 피험자가 음높이 정보에
의존하여 판단하는 경향을 보였다.

\subsection{2. 발화 속도}

노년 화자는 청년 화자보다 평균적으로 20 25\% 발화 속도가 느리며, 더 많은 호흡 휴지를 갖는다(Jacewicz et al., 2009; Linville, 2001; Ramig, 1983). Lee et al. (2017)에 따르면, 낭독 자료 분석 결 과 한국어의 발화 속도에 가장 큰 영향을 미치는 변수는 세대였 으며, 장년층(50 65세)의 발화는 청년층(20 35세)에 비해 유의 미하게 느린 것으로 나타났다. 또한, 장년층은 조음 시간이 더 길 었으며, 휴지를 더 잦고 길게 실현하는 경향이 있었다.

본 연구에서도 연령과 발화 속도 간의 관련성을 확인할 수 있 었다. 60 70대 집단은 낭독 발화 과제에서 현저히 느린 발화 속도 를 보였으며(평균 $4.5 \mathrm{sps}(S D 0.73))$, 집단 간 차이가 줄어들기는 했으나 자유 발화 과제에서도 다른 화자 집단보다 느린 발화 속 도를 보였다(평균 $3.8 \mathrm{sps}(S D$ 0.91)).

피험자들 역시 화자들의 발화 속도에 민감하였으며, 느린 발 화일수록 나이 많은 화자의 음성이라 판단하는 경향을 보였다. 자유 발화에서 화자들은 대체로 4 7 sps의 속도로 발화하였으며, 발화 속도가 $3 \mathrm{sps}$ 미만인 화자들은 모두 50 대 후반 이상으로 지 각되었다. 그리고 낭독 발화에서 화자들은 대체로 5 8 sps의 속도 로 발화하였으며, 낭독 속도가 $4.5 \mathrm{sps}$ 미만인 화자들은 대체로 60 대 이상으로 판단되었다(4명 중 1 명은 50 대로 판단되었다).

그리고 자유 발화보다 낭독 발화에서 발화 속도 정보가 더욱 적극적으로 활용되었다는 사실도 흥미롭다. 우선, 연령에 따른 화자 간 발화 속도의 차이가 낭독 발화에서 더 뚜렷하였다. 발화 속도 값의 범위도 자유 발화가 2.9 7 sps, 낭독 발화가 3.3 8 sps로, 낭독 발화의 범위가 더 넓었다. 또한, 낭독 발화는 화자들이 동일 한 문장을 발화하였으므로 화자 간에 조음 속도나 휴지의 패턴을 비교하기 더욱 용이한 측면이 있다. 게다가 준비된 대본을 읽는 방식이므로 별도의 발화 계획이 필요하지 않아서, 발화 계획 과 정에서 발생할 수 있는 휴지가 나타나지 않는다. 그러므로 휴지 의 횟수와 길이에서도 연령적인 차이가 드러나고 이를 피험자들 이 파악할 수 있었을 것이다.

실제로 60 70대 화자 집단은 확연히 느린 속도로 낭독을 수행 하였다. 또한, 자유 발화에서보다 낭독 발화에서 화자 간 속도 편 차가 더 크게 나타났다. 그리고 젊은 화자들에 비해 휴지의 빈도 가높고, 그 길이도 긴 경향을 보였다. 따라서 피험자들은 이러한 단서를 연령 지각에 더욱 적극적으로 활용하였을 것이다. 그 결 과로 낭독 발화에서 발화 속도와 PA 간의 상관이 상대적으로 더 강하게 나타난 것으로 해석된다.

더불어, 성별과 발화 속도 변수 간의 상호작용 효과도 관찰되 었다. 본 연구에서는 자유 및 낭독 발화 과제에서 모두 여성 화자 집단의 발화 속도 범위(자유 2.9 7.0 sps, 낭독 3.3 8.0 sps)가 남성 화자 집단(자유 2.9 6.7 sps, 낭독 4.7 8.0 sps)보다 넓게 나타났다. 화자간의 차이도 여성이 남성보다 뚜렷하게 나타나피험자들이 여성 화자들 간의 발화 속도 차이를 더 쉽게 지각하고, 이를 연령 판단에 단서로 삼았을 것으로 보인다.

요약하면, 발화 속도 단서는 화자의 연령을 판단하는 데에 적 
극적으로 이용된 음성적 단서라 할 수 있다. 그리고 화자에 따른 조음의 빠르기와 휴지의 패턴 차이를 파악하기 용이한 낭독 발화 과제에서 이러한 단서가 더욱 결정적인 역할을 하고 있음을 확인 할 수 있었다.

\section{5. 결론}

본고에서는 20 대 한국어 모어 화자 총 80 명을 대상으로, 10 초 내외의 음성을 듣고 화자의 연령을 추측하도록 하는 지각 실험을 실시하였다. 실험 결과, 자극의 유형에 따라 정도의 차이는 있었 으나, 피험자들은 대체로 상당히 정확하게 화자의 연령을 추정한 다는 사실을 확인할 수 있었다(자유 발화 $R^{2}=0.89$, 낭독 발화 $R^{2}=0.90$, 모음 발성 $\left.R^{2}=0.54, p<.001\right)$. 이러한 연령 지각과 관련된 단서 가운데, 본고는 음높이와 발화 속도에 주목하였으며, 음높 이보다는 발화 속도가 연령 지각과 더 밀접한 관련을 보이고 있 음을 확인할 수 있었다.

연령 지각 실험에서 피험자의 정확도는 얼마나 구체적으로 답 변을 하도록 하는가에 따라서 좌우된다. 본 연구에서는 범주적 판단(예를 들면 ‘청년' 혹은 ‘노년')이 아닌 구체적 판단(예컨대 '29세')을 요구하였음에도 불구하고, 피험자들은 매우 높은 정확 도를 보여주었다는 점은 특기할 만하다. 또한, 자유 발화, 낭독 발 화, 모음 발성 등 서로 다른 세 가지 과제에 대한 피험자들의 연령 지각 양상 결과를 비교함으로써, 연령 지각에 대해 다각적으로 접근할 수 있었다.

추후 연구에서는 피험자를 50 대 이상으로 확대하여 비교 연구 를 수행하는 것도 흥미로울 것이다. Huntley et al. (1987)에서 주목 하였던 것처럼, 피험자의 특성이 화자의 연령을 판단하는 데에 영향을 미치는 요인일 수 있다. 본 연구 결과에 따르면, 피험자의 성별과 연령은 화자의 연령을 판단하는 데 어느 정도 영향이 있 었던 것으로 보인다. 이를 검증하기 위해서는 피험자 집단의 연 령을 다변화하고 규모를 확대하여 살펴야 할 것이다.

아울러, 연령 지각에 영향을 줄 수 있는 다른 음성적 단서에 대 한 검토도 필요할 것이다. 본 연구에서는 판단에 주요한 역할을 할 것이라 기대되고, 선행 연구에서 주로 다루어진 음높이와 발 화 속도만을 대상으로 연구를 진행하였다. 그러나 음높이의 경우 에는 연령 지각에 결정적인 단서가 된다고 보기는 어려웠다. 따 라서 후속 연구에서는 평균 fo 외의 다른 음성적 파라미터를 검토 하여, 피험자들의 연령 추정 메커니즘에 대한 보다 심층적인 논 의가 이루어져야 할 것이다.

\section{References}

Baken, R. J. (2005). The aged voice: A new hypothesis. Journal of Voice, 19(3), 317-325.

Harnsberger, J. D., Shrivastav, R., Brown, W. S., Rothman, H., \& Hollien, H. (2008). Speaking rate and fundamental frequency as speech cues to perceived age. Journal of Voice, 22(1), 58-69.

Horii, Y. \& Ryan, W. J. (1981). Fundamental frequency characteristics and perceived age of adult male speakers. Folia Phoniatrica et Logopaedica, 33(4), 227-233.

Huntley, R., Hollien, H., and Shipp, T. (1987). Influences of listener characteristics on perceived age estimations. Journal of Voic,. 1(1), 49-52.

Jacewicz, E., Fox, R. A., O’Neill, C., \& Salmons, J. (2009). Articulation rate across dialect, age, and gender. Language Variation and Change, 21, 233-256.

Kim, J., \& Seong, C. (2014). Listener's age estimation by prosody manipulation. Phonetics and Speech Sciences, 6(2), 81-88.

Lee, N., Shin, J., Yoo, D., \& Kim, K. W. (2017). Speech rate in Korean across region, gender and generation. Phonetics and Speech Sciences, 9(1), 27-39.

Linville, S. E. (2001). Vocal aging. San Diego, CA: Singular Thomson Learning.

Neiman, G. S., \& Applegate, J. A. (1990). Accuracy of listener judgments of perceived age relative to chronological age in adults. Folia Phoniatrica et Logopaedica, 42(6), 327-330.

Ptacek, P. H., \& Sander, E. K. (1966). Age recognition from voice. Journal of Speech and Hearing Research, 9(2), 273-277.

Ramig, L. A. (1983). Effects of physiological aging on speaking and reading rates. Journal of Communication Disorders, 16(3), 217226.

Ryan, W. J., \& Burk, K. W. (1974). Perceptual and acoustic correlates of aging in the speech of males. Journal of Communication Disorders, 7(2), 181-192.

Schotz, S. (2007). Acoustic analysis of adult speaker age. In C. Muller (Ed.), Speaker classification I: Fundamentals, features, and methods, (vol. 1, pp. 88-107). Heidelberg, Germany: Springer.

Shin, J., \& Kim, K. W. (2017). Developing a Korean standard speech DB (II). Phonetics and Speech Sciences, 9(2), 9-22.

Shipp, T., \& Hollien, H. (1969). Perception of the aging male voice. Journal of Speech and Hearing Research, 12(4), 703-710.

\footnotetext{
- 서윤정 (Yoon-Jeong Seo) 고려대학교 국어국문학과 서울시 성북구 안암로 145 Tel: 02-3290-2505 Email:phon_etic@naver.com 관심분야: 음성학, 음운론

- 신지영 (Jiyoung Shin) 교신저자 고려대학교 국어국문학과 서울시 성북구 안암로 145 Tel: 02-3290-1973 Email: shinjy@korea.ac.kr 관심분야: 음성학, 음운론
} 


\title{
화자 연령 지각과 음성적 특성: 음높이와 발화 속도를 중심으로*
}

\author{
서 윤 정·신 지 영 \\ 고려대학교 국어국문학과
}

\section{국문초록}

본고는 한국인 피험자를 대상으로 지각 실험을 진행하여 화자의 실제 연령(Chronological age)과 지각 연령 (Perceived age) 간의 상관관계를 살피고, 한국인 피험자가 얼마나 정확하게 익명의 화자의 연령을 지각할 수 있는지 를 밝히고자 한다. 또한, 이러한 연령 지각에 음성적 단서가 되는 음높이와 발화 속도와 지각 연령 간의 영향 관계 를 검토하고자 한다. 이를 위해, 성인 80 명을 대상으로 3 가지 과제로 구성된 지각 실험을 진행하였다. 실험 자극은 표준어 화자 40 명에게서 추출되었으며, 자유 발화, 낭독 발화, 모음 연장 발성으로 구성되었다. 각 실험은 10 초 내 외의 음성을 듣고 연령을 구체적인 숫자로 답하는 방식으로 진행되었다. 분석 결과, 한국인 피험자들은 상당히 높 은 판단 정확도를 보였으며, 모음 연장 발성을 들었을 때보다 자유 발화와 낭독 발화를 들었을 때 화자의 연령을 더 욱 정확하게 짐작하였다. 이러한 결과는 음성이 포함하고 있는 정보량의 차이에 기인한 것으로 보인다. 또한, 음성 분석을 수행한 결과 피험자들은 화자의 음높이와 발화 속도를 참고하여 화자의 연령을 추정하는 것으로 나타났으 며, 음높이보다는 발화 속도가 연령 지각에 더 적극적으로 기여한 것으로 나타났다.

핵심어: 연령 지각, 지각 실험, 음높이, 발화 속도

\section{참고문헌}

김지연, 성철재(2014). 운율 변조 양상에 따른 청자의 연령 지각.

말소리와 음성과학, 6(2), 81-88.

신지영, 김경화(2017). 한국인 표준 음성 $\mathrm{DB}$ 구축(II). 말소리와 음성과학, 9(2), 9-22.

이나라, 신지영, 유도영, 김경화(2017). 한국어 발화 속도의 지역, 성별, 세대에 따른 특징 연구. 말소리와 음성과학, 9(1), 27-39.

\footnotetext{
* 이 논문은 2017년 대한민국 교육부와 한국연구재단의 지원을 받아 수행된 연구임 (NRF-2017S1A5A2A01024742).
} 